\title{
Possibility of the Use of Public Microarray Database for Identifying Significant Genes Associated with Oral Squamous Cell Carcinoma
}

\author{
Ki-Yeol Kim ${ }^{1}$ and In-Ho Cha ${ }^{1,2 *}$ \\ ${ }^{1}$ Oral Cancer Research Institute, College of Dentistry, \\ Yonsei University, Seoul 120-752, Korea, ${ }^{2}$ Department \\ of Oral and Maxillofacial Surgery, College of Dentistry, \\ Yonsei University, Seoul 120-752, Korea
}

\begin{abstract}
There are lots of studies attempting to identify the expression changes in oral squamous cell carcinoma. Most studies include insufficient samples to apply statistical methods for detecting significant gene sets. This study combined two small microarray datasets from a public database and identified significant genes associated with the progress of oral squamous cell carcinoma. There were different expression scales between the two datasets, even though these datasets were generated under the same platforms - Affymetrix U133A gene chips. We discretized gene expressions of the two datasets by adjusting the differences between the datasets for detecting the more reliable information. From the combination of the two datasets, we detected 51 significant genes that were upregulated in oral squamous cell carcinoma. Most of them were published in previous studies as cancer-related genes. From these selected genes, significant genetic pathways associated with expression changes were identified. By combining several datasets from the public database, sufficient samples can be obtained for detecting reliable information. Most of the selected genes were known as cancer-related genes, including oral squamous cell carcinoma. Several unknown genes can be biologically evaluated in further studies.
\end{abstract}

Keywords: combined dataset, genetic pathway, oral squamous cell carcinoma, public microarray database, significant gene

\section{Introduction}

Despite recent advances in surgical, radiation, and che-

*Corresponding author: E-mail cha8764@yuhs.ac

Tel +82-2-2228-3140, Fax +82-2-392-2959

Received 1 February 2012, Revised 16 February 2012, Accepted 18 February 2012 motherapeutic treatment protocols, the prognosis of oral squamous cell carcinoma (OSCC) remains mournful, with an approximate $50 \% 5$-year mortality rate from disease or associated complications [1]. Therefore, the identification of biological markers is essential to make progress in detecting malignancy at an early stage and developing novel therapies [2].

Microarray datasets that are created for the same research purposes in different laboratories have accumulated rapidly. The results from different datasets are often inconsistent due to the utilization of different platforms, sample preparations, or various technical variations. If we could combine such datasets by adjusting for systematic biases that exist among different datasets derived from different experimental conditions, the power of statistical tests would be improved by the increase in sample size [3].

In OSCC, although lots of microarray-based studies have been conducted to provide insights into gene expression changes, most of these studies have contained insufficient samples for detecting reliable information using statistical analysis [4, 5]. Therefore, this study attempted to combine several datasets in the public database for detecting significant genes.

We used two small microarray datasets of OSCC for this study, which were based on the same platform but had different expression scales. These two datasets were combined after discretization, because a previous study showed that classification could be improved using combined datasets after discretization [3]. After combining datasets, we used chi-square test for identifying the significant genes. Chi-square test has been used commonly to detect differentially expressed genes after discretization of expression intensities in the microarray experiment.

In this study, gene expression ratios of two datasets were transformed with their ranks for each dataset. Next, the transformed datasets were combined, and a nonparametric statistical method was applied to the combined dataset to detect informative genes. Finally, we showed that most of the selected genes were known to be involved in various cancers, including OSCC 
24 Genomics \& Informatics Vol. 10(1) 23-32, March 2012

Table 1. Summaryof two microarray datasets from GEO and the combined dataset

\begin{tabular}{lccccc}
\hline \multicolumn{1}{c}{ Data name } & Experimental platform & No. of genes & $\begin{array}{c}\text { No. of total } \\
\text { samples }\end{array}$ & Normal group & Tumor group \\
\hline Data 2004 [4] & Affymetrix U133A & 14,119 & 20 & 4 & 16 \\
Data 2005 [5] & Affymetrix U133A & 22,283 & 27 & 5 & 22 \\
Combined dataset & & 14,119 & 47 & 9 & 38 \\
\hline
\end{tabular}

GEO, Gene Expression Omnibus.

Table 2. Combination of contingency tables for three datasets $\left(t_{i j}=a_{i j}+b_{i j}+c_{i j}\right)$

\begin{tabular}{|c|c|c|c|c|c|c|c|c|c|c|c|c|c|c|c|}
\hline & \multicolumn{3}{|c|}{ Dataset A } & & \multicolumn{3}{|c|}{ Dataset B } & & \multicolumn{3}{|c|}{ Dataset C } & & \multicolumn{3}{|c|}{ Combined dataset } \\
\hline & $\mathrm{P} 1$ & P2 & P3 & & $\mathrm{P} 1$ & P2 & P3 & & $\mathrm{P} 1$ & $\mathrm{P} 2$ & P3 & & $\mathrm{P} 1$ & $\mathrm{P} 2$ & P3 \\
\hline E1 & $a_{11}$ & $a_{12}$ & $a_{13}$ & & $b_{11}$ & $b_{12}$ & $b_{13}$ & & $\mathrm{c}_{11}$ & $\mathrm{c}_{12}$ & $\mathrm{C}_{13}$ & & $t_{11}$ & $t_{12}$ & $t_{13}$ \\
\hline E2 & $a_{21}$ & $a_{22}$ & $a_{23}$ & + & $b_{21}$ & $b_{22}$ & $\mathrm{~b}_{23}$ & + & $\mathrm{c}_{21}$ & $\mathrm{c}_{22}$ & $\mathrm{C}_{23}$ & $=$ & $t_{21}$ & $t_{22}$ & $\mathrm{t}_{23}$ \\
\hline E3 & $a_{31}$ & $a_{32}$ & $a_{33}$ & & $b_{31}$ & $b_{32}$ & $b_{33}$ & & $\mathrm{c}_{31}$ & $\mathrm{C}_{32}$ & $\mathrm{C}_{33}$ & & $t_{31}$ & $t_{32}$ & $t_{33}$ \\
\hline
\end{tabular}

P1, P2, and P3 represent the three different phenotypes. E1, E2, and E3 represent three groups by rank of gene expressions. $a_{i j}, b_{i j}$, and $C_{i j}$ are the numbers of experiments belonging to $P_{j}$ and $E_{i}$ at the same time in data $A$, data $B$, and data $C$, respectively.

\section{Methods}

\section{Dataset}

Two microarray datasets were used for this study. We acquired these datasets from a public database (Gene Expression Omnibus, GEO). One was the expression dataset of 16 tumors and 4 normal tissues from 16 patients, using Affymetrix U133A gene chips (Affymetrix, Santa Clara, CA, USA). The other microarray dataset consisted of expression profiles of 22 tumors and 5 normal tissues. These two datasets were experimented on under the same platform, Affymetrix U133A. The datasets are summarized in Table 1.

\section{Process for combining datasets}

For combining datasets, gene expression ratios are rearranged in order of expression ratios by each gene in each dataset, and the ranks are matched with the corresponding experimental group. If the experimental groups are homogenous, the ranks within the same experimental group would be neighboring. The process of discretization of gene expressions is summarized in the following steps [3]:

(1) Rank the gene expression ratios within a gene for each dataset.

(2) List in order of the ranks, and assign the order of gene expressions to the corresponding experimental groups.

(3) Summarize the result of (2) in the form of a contingency table for each gene.

(4) Combine the contingency tables that have been
Table 3. Summary of discretized data using ranks of gene expressions

\begin{tabular}{llllll}
\hline & & \multicolumn{4}{c}{$\begin{array}{c}\text { Experimental groups by } \\
\text { phenotypes }\end{array}$} \\
\cline { 3 - 7 } & & $\mathrm{P} 1$ & $\mathrm{P} 2$ & $\mathrm{P} 3$ & $\begin{array}{c}\text { Marginal } \\
\text { sum }\end{array}$ \\
\cline { 3 - 7 } & & $\mathrm{n}_{11}$ & $\mathrm{n}_{12}$ & $\mathrm{n}_{13}$ & $\mathrm{r}_{1}$ \\
Experimental group & $\mathrm{E} 1$ & $\mathrm{n}_{22}$ & $\mathrm{n}_{23}$ & $\mathrm{r}_{2}$ \\
by rank of gene & $\mathrm{E} 2$ & $\mathrm{n}_{21}$ & $\mathrm{n}_{22}$ & $\mathrm{r}_{3}$ \\
expression & E3 & $\mathrm{n}_{31}$ & $\mathrm{n}_{32}$ & $\mathrm{n}_{33}$ & $\mathrm{r}_{3}$ \\
Marginal sum & & $\mathrm{C}_{1}$ & $\mathrm{C}_{2}$ & $\mathrm{C}_{3}$ & $\mathrm{n}$ \\
\hline
\end{tabular}

summarized for each dataset.

When there are three datasets to be combined, the datasets can be added as a single entry, as shown in Table 2, after the transformation of each dataset by rank.

\section{Identification of significant genes from a com- bined dataset}

After the summarization of gene expression ratios in the form of a contingency table for each gene, as shown in Table 3, a nonparametric statistical method was applied to the datasets for independence testing between gene expression patterns and experimental groups. The test statistics are calculated as follows for each gene:

$$
\chi^{2}=\sum \frac{\left[n_{i j}-\hat{E}\left(n_{i j}\right)\right]^{2}}{\hat{E}\left(n_{i j}\right)}, \hat{E}\left(n_{i j}\right)=\frac{r_{i} c_{j}}{n}
$$

When the sample size is small - generally $\hat{E}\left(n_{i j}\right)$ less than 5 - Fisher's exact test is recommended rather than chi-square test. 
The significant genes can be selected by an independence test between the phenotypes and gene expressions using this type of summarized dataset. $c_{i}$ and $r_{i}$ represent the marginal sums of the $t^{t h}$ column and row, respectively. $n_{i j}$ is the number of experiments belonging to $E_{\mathrm{i}}$ and $\mathrm{P}_{\mathrm{j}}$, and $n$ represents the total number of experiments.

\section{Results}

The clinical information and expression levels of two da-

Table 4. Summary of two microarray datasets

\begin{tabular}{lcc}
\hline & Data 2004 & Data 2005 \\
\hline Subgroup & & \\
Tumor & 16 & 22 \\
Normal & 4 & 5 \\
Sex & & \\
Male & 15 & 21 \\
Female & 5 & 6 \\
Age (mean, standard deviation) & $56.9(10.22)$ & $60.03(14.16)$ \\
Primary site & & \\
Tongue & 7 & 16 \\
Floor of mouth & 9 & 5 \\
Other & 4 & 6 \\
T stage & & \\
T1 & 1 & 4 \\
T2 & 7 & 8 \\
T3 & 1 & 4 \\
T4 & 9 & 10 \\
Missing & 2 & 1 \\
\hline
\end{tabular}

tasets are summarized in Table 4 and Fig. 1. Subgroup and sex were similarly distributed in the two datasets. The distributions of other factors were not included.

The scale of expression levels in the two datasets was different; the expression values of Data 2004 ranged from 0.01 to 740 , and those of Data 2005 were from 0.1 to 19,773 . The expression patterns of the two datasets can be explored in Fig. 1.

Lots of outliers are shown in Fig. 1A in the two datasets containing whole gene sets. However, in subsets of significant genes, the expression ranges got narrow, and the outliers were decreased (Fig. 1B). The expressions of tumor tissues in Data 2004 were upregulated and varied compared with normal tissues. If there was no outlier with a maximum value in the 14th tumor tissue in Data 2004, the expressions of the two different groups would be clearly distinguished. Any clear differences in expression were not shown between the two groups in Data 2005.

\section{Upregulated 51 genes in oral squamous cell car- cinoma}

To identify differently expressed genes between normal and tumor tissues, we performed chi-square test using a combined microarray dataset. Fifty-one significant genes were selected from a combined dataset with p-value less than 0.005 , which were upregulated in OSCC tissues. The significance level can be controlled, and more genes can be selected with a lower significance level. These selected genes are summarized in Table 5.
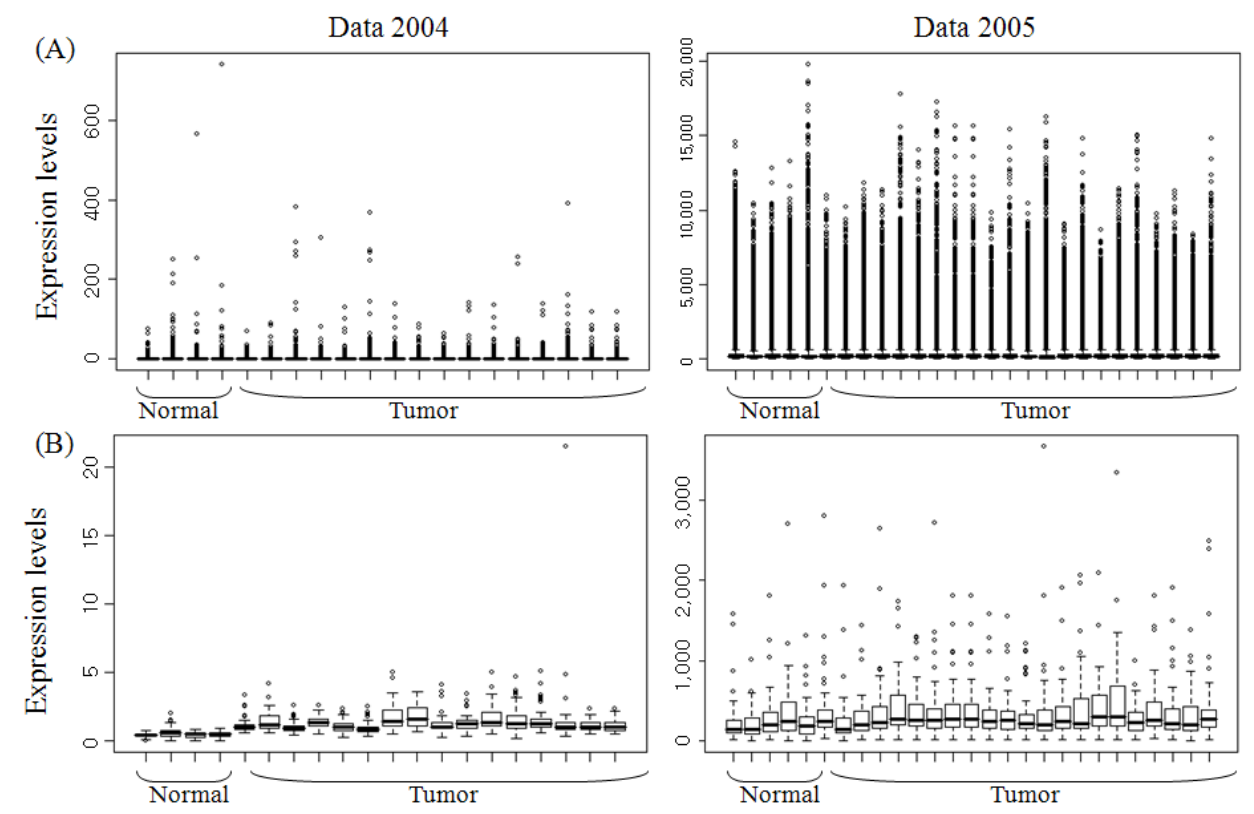

Fig. 1. Comparison of expression levels of two datasets. (A) Whole gene set. (B) Selected gene set. 
Many genes among the selected genes were known as cancer-related genes. STAT1 [6], SKP2 [7], IFI16 [8], RHEB [9], FIF44 [10], SOD2 [11, 12], and GREM1 [11] are related to OSCC. Table 6 [13-56] summarizes the previous studies that have published the relations of selected genes with cancer.

Table 5. Summary of selected 51 upregulated genes

\begin{tabular}{|c|c|c|c|}
\hline Affymetrix No. & Gene & Description & Fold change \\
\hline 200037_s_at & $\mathrm{CBX} 3$ & Chromobox homolog 3 (hp1 gamma homolog, drosophila) & 2.219978 \\
\hline 200056_s_at & C1D & Nuclear dna-binding protein & 2.448721 \\
\hline 200887_s_at & STAT1 & Signal transducer and activator of transcription $1,91 \mathrm{kda}$ & 4.307249 \\
\hline 201091_s_at & $\mathrm{CBX} 3$ & Chromobox homolog 3 (hp1 gamma homolog, drosophila) & 3.647541 \\
\hline 201486_at & $\mathrm{RCN} 2$ & Reticulocalbin 2, ef-hand calcium binding domain & 2.279745 \\
\hline 201518_at & CBX1 & Chromobox homolog 1 (hp1 beta homolog drosophila) & 2.132493 \\
\hline 201663_s_at & SMC4 & Smc4 structural maintenance of chromosomes 4 -like 1 (yeast) & 2.434400 \\
\hline 202633_at & TOPBP1 & Topoisomerase (dna) ii binding protein 1 & 2.189444 \\
\hline 203038_at & PTPRK & Protein tyrosine phosphatase, receptor type, $\mathrm{k}$ & 3.345238 \\
\hline 203301_s_at & DMTF1 & Cyclin $d$ binding myb-like transcription factor 1 & 1.378319 \\
\hline 203562_at & FEZ1 & Fasciculation and elongation protein zeta 1 (zygin i) & 2.853794 \\
\hline 203566_s_at & AGL & Amylo-1, 6-glucosidase, 4-alpha-glucanotransferase & 2.114894 \\
\hline 203595_s_at & IFIT5 & Interferon-induced protein with tetratricopeptide repeats 5 & 2.664490 \\
\hline 203625_x_at & SKP2 & S-phase kinase-associated protein 2 (p45) & 2.007377 \\
\hline 203744_at & HMGB3 & High-mobility group box 3 & 2.974931 \\
\hline 203964_at & NMI & $\mathrm{N}$-myc (and stat) interactor & 3.840395 \\
\hline 204211_x_at & EIF2AK2 & Eukaryotic translation initiation factor 2-alpha kinase 2 & 1.994068 \\
\hline 204439_at & IFI44L & Interferon-induced protein 44 -like & 124.396853 \\
\hline 204822_at & TTK & ttk protein kinase & 2.414220 \\
\hline 204825_at & MELK & Maternal embryonic leucine zipper kinase & 3.755818 \\
\hline 206765_at & KCNJ2 & Potassium inwardly-rectifying channel, subfamily j, member 2 & 1.810372 \\
\hline 207438_s_at & SNUPN & rna, u transporter 1 & 1.913825 \\
\hline 208079_s_at & AURKA & Aurora kinase a & 3.848891 \\
\hline 208966_x_at & IFI16 & Interferon, gamma-inducible protein 16 & 2.568727 \\
\hline 209095_at & DLD & Dihydrolipoamide dehydrogenase & 1.476130 \\
\hline 209524_at & HDGFRP3 & Hepatoma-derived growth factor, related protein 3 & 2.724985 \\
\hline 209903_s_at & ATR & Ataxia telangiectasia and rad3-related & 1.635679 \\
\hline 210283_x_at & PAIP1 & Poly(a) binding protein interacting protein 1 & 1.997611 \\
\hline $211725 \_$s_at & $\mathrm{BID}$ & bh3 interacting domain death agonist & 3.476190 \\
\hline 211727_s_at & $\operatorname{cox} 11$ & Cox 11 homolog, cytochrome $\mathrm{c}$ oxidase assembly protein & 1.419895 \\
\hline 212314_at & KIAA0746 & kiaa0746 protein & 10.323529 \\
\hline 212765_at & CAMSAP1L1 & Calmodulin-regulated spectrin-associated protein 1-like 1 & 1.717589 \\
\hline 212959_s_at & GNPTAB & Hypothetical protein dkfzp762b226 & 1.733743 \\
\hline 213008_at & FANCl & kiaa1794 & 2.935005 \\
\hline 213104_at & C16ORF42 & Hypothetical protein mgc24381 & 2.059115 \\
\hline 213294_at & CCDC75 & Coiled-coil domain-containing 75 & 4.261916 \\
\hline 213404_s_at & RHEB & ras homolog enriched in brain & 1.536225 \\
\hline 213452_at & ZNF184 & Zinc finger protein 184 (kruppel-like) & 1.534287 \\
\hline 213679_at & ТTС30A & Hypothetical protein flj 13946 & 2.374943 \\
\hline 214453_s_at & IFI44 & Interferon-induced protein 44 & 11.920148 \\
\hline 215223_s_at & SOD2 & Superoxide dismutase 2 , mitochondrial & 4.950142 \\
\hline 215495_s_at & SAMD4A & Sterile alpha motif domain containing $4 a$ & 3.204074 \\
\hline 216841_s_at & SOD2 & Superoxide dismutase 2, mitochondrial & 4.790233 \\
\hline 217901_at & DSG2 & Desmoglein 2 & 5.614525 \\
\hline 218469_at & GREM1 & Gremlin 1 , cysteine knot superfamily, homolog & 3.366686 \\
\hline 218627_at & DRAM & Damage-regulated autophagy modulator & 2.780824 \\
\hline 218901_at & PLSCR4 & Phospholipid scramblase 4 & 3.663654 \\
\hline 218986_s_at & FLJ20035 & Hypothetical protein flj10787 & 6.364550 \\
\hline 219087_at & ASPN & Asporin (Irr class 1) & 7.895878 \\
\hline 219372_at & IFT81 & Intraflagellar transport 81 homolog (chlamydomonas) & 1.875798 \\
\hline 219787_s_at & ECT2 & Epithelial cell transforming sequence 2 oncogene & 4.242975 \\
\hline
\end{tabular}


Table 6. Association of the selected genes and cancer

\begin{tabular}{|c|c|c|c|c|c|}
\hline Gene & $\begin{array}{l}\text { Cancer } \\
\text { association }\end{array}$ & References & $\begin{array}{c}\text { OSCC } \\
\text { association }\end{array}$ & References & Fold change \\
\hline СвX3 & & & & & 2.219978 \\
\hline C1D & Yes & Yang et al. [13] & & & 2.448721 \\
\hline STAT1 & Yes & $\begin{array}{l}\text { Hiroi et al. [6] } \\
\text { Laimer et al. [15] }\end{array}$ & Yes & Hiroi et al. [14] & 4.307249 \\
\hline RCN2 & Yes & Cavallo et al. [16] & & & 2.279745 \\
\hline CBX1 & Yes & Luo et al. [17] & & & 2.132493 \\
\hline SMC4 & & & & & 2.434400 \\
\hline TOPBP1 & Yes & Going et al. [18] & & & 2.189444 \\
\hline PTPRK & Yes & $\begin{array}{l}\text { Starr et al. [19] } \\
\text { Flavell et al. [20] }\end{array}$ & & & 3.345238 \\
\hline DMTF1 & Yes & van Dekken et al. [21] & & & 1.378319 \\
\hline FEZ1 & Yes & $\begin{array}{l}\text { Califano et al. [22] } \\
\text { Chen et al. [23] }\end{array}$ & & & 2.853794 \\
\hline AGL & Yes & Fabris et al. [24] & & & 2.114894 \\
\hline IFIT5 & & & & Ben-Izhak et al. [7] & 2.664490 \\
\hline SKP2 & Yes & Shintani et al. [25] & Yes & & 2.007377 \\
\hline HMGB3 & Yes & Hayes et al. [26] & & & 2.974931 \\
\hline NMI & Yes & $\begin{array}{l}\text { Fillmore et al. [27] } \\
\text { Quaye et al. [28] }\end{array}$ & & & 3.840395 \\
\hline EIF2AK2 & & & & & 1.994068 \\
\hline IFI44L & & & & & 124.396853 \\
\hline TTK & Yes & $\begin{array}{l}\text { Harima et al. [29] } \\
\text { Kono et al. [30] } \\
\text { de Cárcer et al. [31] } \\
\text { Suda et al. [32] }\end{array}$ & & & 2.414220 \\
\hline MELK & Yes & $\begin{array}{l}\text { Pickard et al. [33] } \\
\text { Kappadakunnel et al. [34] }\end{array}$ & & & 3.755818 \\
\hline KCNJ2 & Yes & Gałeza-Kulik et al. [35] & & & 1.810372 \\
\hline SNUPN & & & & & 1.913825 \\
\hline AURKA & Yes & $\begin{array}{l}\text { Torchia et al. [36] } \\
\text { Chen et al. [37] } \\
\text { Kaestner et al. [38] }\end{array}$ & & De Andrea et al. [8] & 3.848891 \\
\hline IFl16 & Yes & $\begin{array}{l}\text { Alimirah et al. [39] } \\
\text { Zhang et al. [40] }\end{array}$ & Yes & & 2.568727 \\
\hline DLD & & Ortega-Paino et al. [41] & & & 1.476130 \\
\hline HDGFRP3 & Yes & & & & 2.724985 \\
\hline ATR & & & & & 1.635679 \\
\hline PAIP1 & & & & & 1.997611 \\
\hline BID & & Ahmed et al. [42] & & & 3.476190 \\
\hline Cox11 & Yes & & & & 1.419895 \\
\hline KIAA0746 & & & & & 10.323529 \\
\hline CAMSAP1L1 & & & & & 1.717589 \\
\hline GNPTAB & & Zhi et al. [43] & & & 1.733743 \\
\hline $\mathrm{FANCl}$ & Yes & Barroso et al. [44] & & & 2.935005 \\
\hline C16ORF42 & & & & & 2.059115 \\
\hline CCDC75 & & & & Chakraborty et al. [9] & 4.261916 \\
\hline RHEB & & & Yes & & 1.536225 \\
\hline ZNF184 & & & & & 1.534287 \\
\hline TTC30A & & Lee et al. [45] & & Ye et al. [11] & 2.374943 \\
\hline IFI44 & Yes & Skrzycki et al. [46] & Yes & Liu et al. [12] & 11.920148 \\
\hline SOD2 & Yes & Olson et al. [47] & Yes & Ye et al. [10] & 4.950142 \\
\hline SAMD4A & & Lorch et al. [48] & & & 4.790233 \\
\hline
\end{tabular}

OSCC, oral squamous cell carcinoma. 
28 Genomics \& Informatics Vol. 10(1) 23-32, March 2012

Table 6. Continued

\begin{tabular}{|c|c|c|c|c|c|}
\hline Gene & $\begin{array}{c}\text { Cancer } \\
\text { association }\end{array}$ & References & $\begin{array}{c}\text { OSCC } \\
\text { association }\end{array}$ & References & Fold change \\
\hline DSG2 & Yes & Lorch et al. [49] & & Ye et al. [11] & 5.614525 \\
\hline GREM1 & & Crighton et al. [50] & Yes & & 3.366686 \\
\hline DRAM & Yes & Crighton et al. [51] & & & 2.780824 \\
\hline PLSCR4 & & & & & 3.663654 \\
\hline FLJ20035 & & Mackay et al. [52] & & & 6.364550 \\
\hline ASPN & Yes & Turashvili et al. [53] & & & 7.895878 \\
\hline IFT81 & & Fields and Justilien [54] & & & 1.875798 \\
\hline \multirow[t]{2}{*}{ ЕСТ2 } & Yes & Boelens et al. [55] & & & 4.242975 \\
\hline & & Hirata et al. [56] & & & \\
\hline
\end{tabular}

OSCC, oral squamous cell carcinoma.

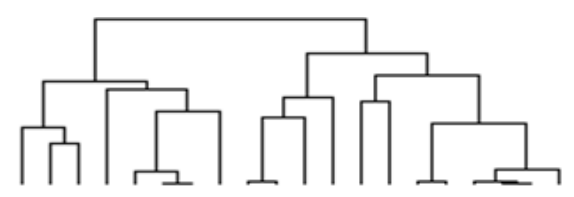

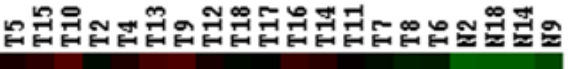

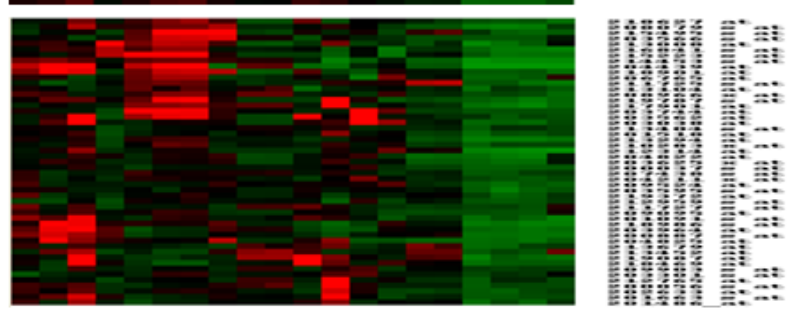

Fig. 2. Expression patterns of the selected 51 genes. These genes were upregulated in oral squamous cell carcinoma tissues, and normal and tumor groups were clearly classified with these genes.

\section{Expression pattern of the identified genes}

To investigate whether the different experimental groups could be classified with significant genes, an unsupervised hierarchical clustering method was applied to the significant gene set (Fig. 2).

The normal group consisted of 4 tissues and showed significantly lower expression levels when compared with the tumor group. In Fig. 2, we investigated the classification availability of the identified genes in Data 2004 , not in a combined dataset, because the two datasets have different expression scales.

\section{Network analysis}

Based on all identified genes, new and expanded path- way maps and connections and specific gene-gene interactions were inferred, functionally analyzed, and used to build on the existing pathway using the Ingenuity Pathway Analysis (IPA) knowledge base [57].

To generate networks in this work, the knowledge base was queried for interactions between the identified genes and all other genes stored in the database. Four networks were found to be significant in OSCC. The network with the highest score (Network 1 , score $=36$ ) was generated, with 17 identified genes (Table 7, Fig. 3).

In the network diagram, STAT1 and SOD2 neighbored with NMI and AURKA, respectively. The expression levels of STAT1 and SOD2 could be expected to be related with those of NMI and SOD2. Actually, the expressions of STAT1 and SOD2 were strongly positively correlated with NMI $(r=0.95)$ and AURKA $(r=0.87)$, respectively.

\section{Discussion}

OSCC is associated with substantial mortality and morbidity [58]. To identify potential biomarkers for early detection of invasive OSCC, microarray experiments have been conducted, and these kinds of microarray datasets have accumulated rapidly in the public database. However, there are many datasets that include insufficient sample sizes for detecting significant genes by statistical analysis. Therefore, this study attempted to combine several microarray datasets from a public database to identify significant candidates as biomarkers.

In a microarray data analysis, the information from different datasets obtained under different experimental conditions may be inconsistent even though they are performed with the same research objectives. Moreover, even when the datasets are generated by the same 
Table 7. Four networks generated by upregulated genes in OSCC

\begin{tabular}{|c|c|c|c|}
\hline Network & Genes Ingenuity networks ${ }^{a}$ & Function & Score ${ }^{b}$ \\
\hline 1 & $\begin{array}{l}\text { Akt, ATR (includes EG:545), AURKA, BID, C11ORF30, CBX1, CBX3, Ck2, Cyclin A, } \\
\text { Cytochrome c, EIF2AK2, ERK, GREM1, GZMK, Histone h3, Histone h4, IFI16, } \\
\text { IFN TYPE 1, IFNA3, Interferon alpha, NFkB (complex), NMI, PDGF BB, PI3K, PIF, } \\
\text { Proteasome, RHEB, SKP2, SMC4, SNUPN, SOD2, STAT1, Tgf beta, TOPBP1, TTK }\end{array}$ & $\begin{array}{l}\text { Cancer, cellular } \\
\text { response to } \\
\text { therapeutics, } \\
\text { cell cycle }\end{array}$ & 36 \\
\hline 2 & $\begin{array}{l}\text { AGL, ASPN, beta-estradiol, BTG1, C1D, CoX11, DDX60, DNAJB4, DSC2, DSG2, } \\
\text { ECT2, FGF13, GBP1 (includes EG:2633), HNF4A, IFI44, IFI44L, IFIT5, IFNA2, } \\
\text { IFNA4, IFNA6, IFNA7, IFNA5 (includes EG:3442), KCNJ2, MAPK14, MST1, MYOG, } \\
\text { NUP153, PARP9, PTPRK, RCN2, SMAD3, SSTR1, TGFB1, TGTP, TMF1 }\end{array}$ & $\begin{array}{l}\text { Cell-mediated immune } \\
\text { response, embryonic } \\
\text { development, antigen } \\
\text { presentation }\end{array}$ & 28 \\
\hline 3 & $\begin{array}{l}\text { CAMSAP1L1, CDC25A, CDKN2A, DHFR, DISC1, DLD, DMTF1, DRAM } \\
\text { (includes EG:55332), E2F4, FANCI, FEZ1, GNB2L1, GNPTAB, HMGB3, IFI202B, } \\
\text { LBR, MCM3, MCM5, MELK, MKI67, MLC1, PABPC1, PAIP1, PDHB, Pias, PLSCR4, } \\
\text { PRMT1, RUVBL2, SAMD4A, SLC2A4, TFDP1, TK1, TP53, TRA2B, YWHAG }\end{array}$ & $\begin{array}{l}\text { Cell cycle, } \\
\text { connective tissue } \\
\text { development and } \\
\text { function, cell death }\end{array}$ & 24 \\
\hline 4 & $\begin{array}{l}\text { CAMSAP1L1, CDC25A, CDKN2A, DHFR, DISC1, DLAT, DLD, DMTF1, DRAM } \\
\text { (includes EG:55332), E2F4, EIF4A, FANCI, FEZ1, GNPTAB, HMGB3, IFI202B, LBR, } \\
\text { MCM3, MCM5, MELK, MKI67, MLC1, PABPC1, PAIP1, PDHB, Pias, PLSCR4, } \\
\text { PRMT1, RUVBL2, SAMD4A, SLC2A4, TFDP1, TP53, TRA2B, YWHAG }\end{array}$ & $\begin{array}{l}\text { Cell cycle, connective } \\
\text { tissue development } \\
\text { and function, } \\
\text { lipid metabolism }\end{array}$ & 24 \\
\hline
\end{tabular}

OSCC, oral squamous cell carcinoma.

${ }^{a}$ Genes in bold were identified in this study; other genes were neither on the expression array data used in this work nor changed significantly; ${ }^{\mathrm{b}} \mathrm{A}$ score $>3$ was considered significant.

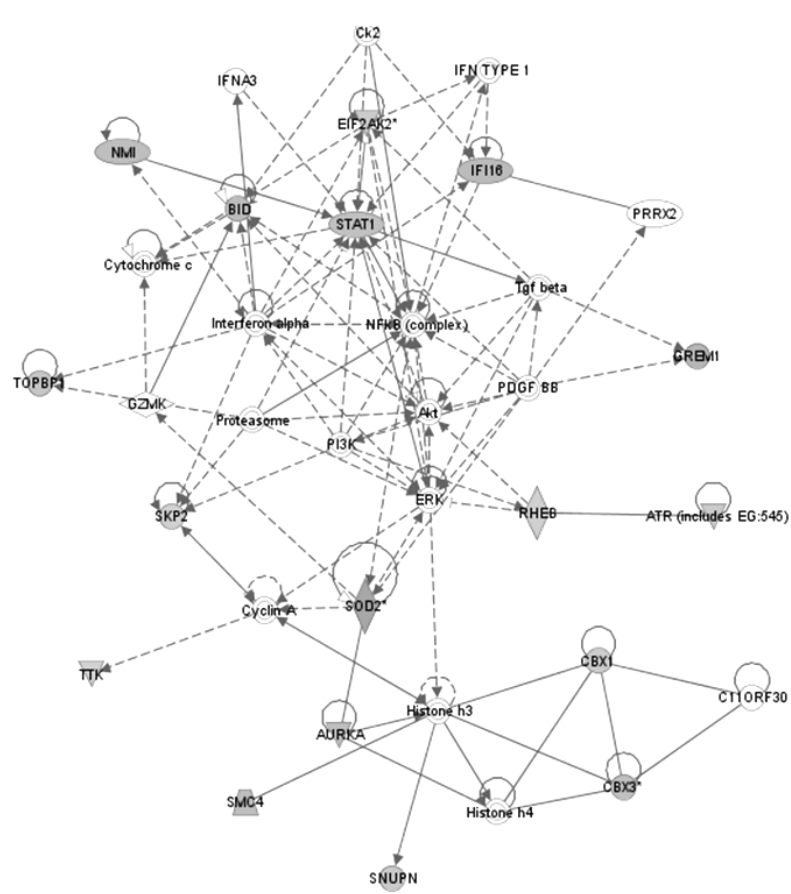

Fig. 3. Network with the highest score (Network 1). Functional relationships between genes based on known interactions in Ingenuity Pathway Analysis (IPA) knowledge are described.

platform, the data agreement may be affected by technical variations between laboratories. In such cases, it could be necessary to use a combined dataset after adjusting for the differences between such datasets for detecting the more reliable information. Combining datasets is especially useful in OSCC microarray datasets, because there are many datasets with insufficient sample sizes for analysis [4, 5, 59, 60].

For identifying significant genes classifying tumor and normal groups, we achieved two microarray datasets from a public database, GEO. They included 20 and 27 samples, and each sample size was unbalanced between the different groups. By combining these two datasets, the sample size was increased, and we had a sufficient sample size for statistical analysis, even though it was still unbalanced. When these datasets were combined, we used the rank of gene expression, because the scale of gene expression was different. In this study, we identified 51 significant genes from a combined dataset, and this number could be increased or decreased by the significance level (we used 0.005). The selected 51 genes were upregulated in tumor tissues. Many of the selected genes were proven to be cancer-related genes by previous studies.

SOD2 is associated with lymph node metastasis in OSCC and may provide predictive values for the diagnosis of metastasis [10]. Metastasis is a critical event in OSCC progression. An SOD2 variant has also been associated with increased breast cancer and ovarian cancer risk in previous studies [47, 61]. TopBP1 included eight BRCT domains (originally identified in BRCA1), and it was proposed as a breast cancer susceptibility gene $[18,62]$.

By semiquantitative reverse transcription PCR analysis, RHEB was shown to be upregulated in OSCC [9]. In salivary cancer, survival probability rates dropped 
when Skp2 was overexpressed [7]. Overexpression of Skp2 is associated with the reduction of p27 (KIP1) expression and may have a role in the progression of OSCC [25].

The expression of RCN2 was linearly related to the tumor mass increase, and its expression was increased in breast cancer [16]. PTPRK was proven as a candidate gene of colorectal cancer [19], and it is a functional tumor suppressor in Hodgkin lymphoma cells [20]. DMTF1 was shown to be amplified in adenocarcinoma of the gastroesophageal junction, residing at $7 \mathrm{q} 21$ by aCGH experiments [21]. FEZ1 was involved in ovarian carcinogenesis, and its reduction or loss could be an aid to the clinical management of patients affected by ovarian carcinoma [22]. It is also a known tumor suppressor gene in breast cancer and gastric cancer [23, 63].

Other ovarian cancer-related genes were NMI $[27,28]$ and FANCl [44]; breast cancer-related genes were COX11 [42], MELK [33], and FANCI [44] among the selected genes. MELK was known to be associated with shorter survival in glioblastoma [34].

TTK was associated with progression and metastasis of advanced cervical cancers after radiotherapy [29, 30]. It might also be a relevant candidate as a new target in cancer therapy, since it plays relevant roles in mitotic progression and the spindle checkpoint [31, 32]. Aurora kinase A (AURKA) was associated with skin tumors [36] and colorectal cancer [37, 38].

In previous studies, OSCC-related genes among the selected genes were STAT1 [14], SKP2 [7, 25], IFI16 [8], RHEB [9], IFI44 [64], SOD2 [10-12], and GREM1 [11]. The gene set, which has not been proven as OSCC-related genes until now, could be expected to be possibly proven as OSCC-related genes by biological evaluation.

In this study, we identified significant genes related with OSCC from two microarray datasets in a public database. For this, we transformed microarray datasets using ranks of gene expressions with different expression scales, even though they were constructed under the same experimental conditions. This method could be useful when using multiple datasets that are created for the same research purpose, By combining these accumulated datasets, we can detect more reliable information due to the increased sample size. It saves time and money and avoids repeating experiments.

\section{Acknowledgments}

This work was supported by the Priority Research Centers Program through the National Research Foundation of Korea (NRF), funded by the Ministry of Education, Science and Technology (2011-0031396).

\section{References}

1. Sparano A, Quesnelle KM, Kumar MS, Wang Y, Sylvester AJ, Feldman M, et al. Genome-wide profiling of oral squamous cell carcinoma by array-based comparative genomic hybridization. Laryngoscope 2006;116: 735-741.

2. Smeets SJ, Brakenhoff $\mathrm{RH}$, Ylstra $B$, van Wieringen WN, van de Wiel MA, Leemans CR, et al. Genetic classification of oral and oropharyngeal carcinomas identifies subgroups with a different prognosis. Cell Oncol 2009;31:291-300.

3. Kim KY, Ki DH, Jeung HC, Chung HC, Rha SY. Improving the prediction accuracy in classification using the combined data sets by ranks of gene expressions. BMC Bioinformatics 2008;9:283.

4. Toruner GA, Ulger C, Alkan M, Galante AT, Rinaggio J, Wilk $\mathrm{R}$, et al. Association between gene expression profile and tumor invasion in oral squamous cell carcinoma. Cancer Genet Cytogenet 2004;154:27-35.

5. O'Donnell RK, Kupferman M, Wei SJ, Singhal S, Weber $\mathrm{R}$, O'Malley B, et al. Gene expression signature predicts lymphatic metastasis in squamous cell carcinoma of the oral cavity. Oncogene 2005;24:1244-1251.

6. Hiroi M, Mori K, Sakaeda Y, Shimada J, Ohmori Y. STAT1 represses hypoxia-inducible factor-1-mediated transcription. Biochem Biophys Res Commun 2009;387: 806-810.

7. Ben-Izhak O, Akrish S, Gan S, Nagler RM. Skp2 and salivary cancer. Cancer Biol Ther 2009;8:153-158.

8. De Andrea M, Gioia D, Mondini M, Azzimonti B, Renò $\mathrm{F}$, Pecorari G, et al. Effects of IFl16 overexpression on the growth and doxorubicin sensitivity of head and neck squamous cell carcinoma-derived cell lines. Head Neck 2007;29:835-844.

9. Chakraborty S, Mohiyuddin SM, Gopinath KS, Kumar A. Involvement of TSC genes and differential expression of other members of the mTOR signaling pathway in oral squamous cell carcinoma. BMC Cancer 2008;8:163.

10. Ye H, Wang A, Lee BS, Yu T, Sheng S, Peng T, et al. Proteomic based identification of manganese superoxide dismutase 2 (SOD2) as a metastasis marker for oral squamous cell carcinoma. Cancer Genomics Proteomics 2008:5:85-94.

11. Ye H, Yu T, Temam S, Ziober BL, Wang J, Schwartz $\mathrm{JL}$, et al. Transcriptomic dissection of tongue squamous cell carcinoma. BMC Genomics 2008;9:69.

12. Liu $X, Y u$ J, Jiang $L$, Wang $A$, Shi $F$, Ye $H$, et al. MicroRNA-222 regulates cell invasion by targeting matrix metalloproteinase 1 (MMP1) and manganese superoxide dismutase 2 (SOD2) in tongue squamous cell carcinoma cell lines. Cancer Genomics Proteomics 2009;6:131139.

13. Yang ZJ, Yang G, Jiang YM, Ran YL, Yang ZH, Zhang $W$, et al. Screening and sero-immunoscreening of ovarian epithelial cancer associative antigens. Zhonghua $\mathrm{Fu}$ Chan Ke Za Zhi 2007;42:834-839.

14. Hiroi M, Mori K, Sekine K, Sakaeda Y, Shimada J, Ohmori $Y$. Mechanisms of resistance to interferon-gammamediated cell growth arrest in human oral squamous 
carcinoma cells. J Biol Chem 2009;284:24869-24880.

15. Laimer K, Spizzo G, Obrist P, Gastl G, Brunhuber T, Schäfer $G$, et al. STAT1 activation in squamous cell cancer of the oral cavity: a potential predictive marker of response to adjuvant chemotherapy. Cancer 2007; 110:326-333

16. Cavallo F, Astolfi A, lezzi M, Cordero F, Lollini PL, Forni $\mathrm{G}$, et al. An integrated approach of immunogenomics and bioinformatics to identify new Tumor Associated Antigens (TAA) for mammary cancer immunological prevention. BMC Bioinformatics 2005;6(Suppl 4):S7.

17. Luo B, Cheung HW, Subramanian A, Sharifnia T, Okamoto $M$, Yang $X$, et al. Highly parallel identification of essential genes in cancer cells. Proc Natl Acad Sci U S A 2008;105:20380-20385.

18. Going JJ, Nixon C, Dornan ES, Boner W, Donaldson MM, Morgan IM. Aberrant expression of TopBP1 in breast cancer. Histopathology 2007;50:418-424.

19. Starr TK, Allaei R, Silverstein KA, Staggs RA, Sarver $\mathrm{AL}$, Bergemann TL, et al. A transposon-based genetic screen in mice identifies genes altered in colorectal cancer. Science 2009;323:1747-1750.

20. Flavell JR, Baumforth KR, Wood VH, Davies GL, Wei W, Reynolds GM, et al. Down-regulation of the TGF-beta target gene, PTPRK, by the Epstein-Barr virus encoded EBNA1 contributes to the growth and survival of Hodgkin lymphoma cells. Blood 2008;111:292301.

21. van Dekken H, Vissers K, Tilanus HW, Kuo WL, Tanke $\mathrm{HJ}$, Rosenberg $\mathrm{C}$, et al. Genomic array and expression analysis of frequent high-level amplifications in adenocarcinomas of the gastro-esophageal junction. Cancer Genet Cytogenet 2006;166:157-162

22. Califano D, Pignata S, Pisano C, Greggi S, Laurelli G, Losito NS, et al. FEZ1/LZTS1 protein expression in ovarian cancer. J Cell Physiol 2010;222:382-386.

23. Chen L, Zhu Z, Sun X, Dong XY, Wei J, Gu F, et al. Down-regulation of tumor suppressor gene FEZ1/LZTS1 in breast carcinoma involves promoter methylation and associates with metastasis. Breast Cancer Res Treat 2009;116:471-478

24. Fabris C, Basso D, Del Favero G, Meggiato T, Piccoli $A$, Angonese $C$, et al. Renal handling of amylase and immunoreactive trypsin in pancreatic cancer and chronic pancreatitis. Clin Physiol Biochem 1990;8:30-37.

25. Shintani S, Li C, Mihara M, Hino S, Nakashiro K, Hamakawa H. Skp2 and Jab1 expression are associated with inverse expression of p27(KIP1) and poor prognosis in oral squamous cell carcinomas. Oncology 2003;65:355-362

26. Hayes DC, Secrist $H$, Bangur CS, Wang T, Zhang $X$, Harlan D, et al. Multigene real-time PCR detection of circulating tumor cells in peripheral blood of lung cancer patients. Anticancer Res 2006;26:1567-1575.

27. Fillmore RA, Mitra A, Xi Y, Ju J, Scammell J, Shevde $\mathrm{LA}$, et al. Nmi (N-Myc interactor) inhibits Wnt/beta-catenin signaling and retards tumor growth. Int $J$ Cancer 2009;125:556-564.

28. Quaye L, Song H, Ramus SJ, Gentry-Maharaj A,
Høgdall E, DiCioccio RA, et al. Tagging single-nucleotide polymorphisms in candidate oncogenes and susceptibility to ovarian cancer. Br J Cancer 2009;100:9931001.

29. Harima $Y$, Ikeda $K$, Utsunomiya $K$, Shiga $T$, Komemushi $\mathrm{A}$, Kojima $\mathrm{H}$, et al. Identification of genes associated with progression and metastasis of advanced cervical cancers after radiotherapy by cDNA microarray analysis. Int J Radiat Oncol Biol Phys 2009;75:1232-1239.

30. Kono K, Mizukami Y, Daigo Y, Takano A, Masuda K, Yoshida $\mathrm{K}$, et al. Vaccination with multiple peptides derived from novel cancer-testis antigens can induce specific T-cell responses and clinical responses in advanced esophageal cancer. Cancer Sci 2009;100:15021509.

31. de Cárcer G, Pérez de Castro I, Malumbres M. Targeting cell cycle kinases for cancer therapy. Curr Med Chem 2007;14:969-985

32. Suda T, Tsunoda T, Daigo $Y$, Nakamura $Y$, Tahara $H$. Identification of human leukocyte antigen-A24-restricted epitope peptides derived from gene products upregulated in lung and esophageal cancers as novel targets for immunotherapy. Cancer Sci 2007 Sep 2 [Epub]. http://dx.doi.org/10.1111/j.1349-7006.2007.00603.x.

33. Pickard MR, Green AR, Ellis IO, Caldas C, Hedge VL, Mourtada-Maarabouni $\mathrm{M}$, et al. Dysregulated expression of Fau and MELK is associated with poor prognosis in breast cancer. Breast Cancer Res 2009;11:R60.

34. Kappadakunnel M, Eskin A, Dong J, Nelson SF, Mischel PS, Liau LM, et al. Stem cell associated gene expression in glioblastoma multiforme: relationship to survival and the subventricular zone. I Neurooncol 2010;96:359-367.

35. Gałeza-Kulik M, Zebracka J, Szpak-Ulczok S, Czarniecka AK, Kukulska A, Gubala E, et al. Expression of selected genes involved in transport of ions in papillary thyroid carcinoma. Endokrynol Pol 2006;57(Suppl A):26-31

36. Torchia EC, Chen $Y$, Sheng $H$, Katayama H, Fitzpatrick $\mathrm{J}$, Brinkley WR, et al. A genetic variant of Aurora kinase A promotes genomic instability leading to highly malignant skin tumors. Cancer Res 2009;69:7207-7215.

37. Chen J, Etzel CJ, Amos Cl, Zhang Q, Viscofsky N, Lindor NM, et al. Genetic variants in the cell cycle control pathways contribute to early onset colorectal cancer in Lynch syndrome. Cancer Causes Control 2009; 20:1769-1777.

38. Kaestner $P$, Stolz A, Bastians $H$. Determinants for the efficiency of anticancer drugs targeting either Aurora-A or Aurora-B kinases in human colon carcinoma cells. Mol Cancer Ther 2009;8:2046-2056.

39. Alimirah F, Chen J, Davis FJ, Choubey D. IFI16 in human prostate cancer. Mol Cancer Res 2007;5:251-259.

40. Zhang Y, Howell RD, Alfonso DT, Yu J, Kong L, Wittig $\mathrm{JC}$, et al. IFI16 inhibits tumorigenicity and cell proliferation of bone and cartilage tumor cells. Front BiosCi 2007; 12:4855-4863.

41. Ortega-Paino E, Fransson J, Ek S, Borrebaeck CA. Functionally associated targets in mantle cell lymphoma 
as defined by DNA microarrays and RNA interference. Blood 2008;111:1617-1624.

42. Ahmed S, Thomas G, Ghoussaini M, Healey CS, Humphreys MK, Platte R, et al. Newly discovered breast cancer susceptibility loci on $3 p 24$ and 17q23.2. Nat Genet 2009;41:585-590.

43. Zhi G, Wilson JB, Chen X, Krause DS, Xiao Y, Jones $\mathrm{NJ}$, et al. Fanconi anemia complementation group FANCD2 protein serine 331 phosphorylation is important for fanconi anemia pathway function and BRCA2 interaction. Cancer Res 2009;69:8775-8783.

44. Barroso E, Pita G, Arias JI, Menendez P, Zamora P, Blanco $\mathrm{M}$, et al. The Fanconi anemia family of genes and its correlation with breast cancer susceptibility and breast cancer features. Breast Cancer Res Treat 2009; 118:655-660

45. Lee ES, Son DS, Kim SH, Lee J, Jo J, Han J, et al. Prediction of recurrence-free survival in postoperative non-small cell lung cancer patients by using an integrated model of clinical information and gene expression. Clin Cancer Res 2008;14:7397-7404.

46. Skrzycki M, Majewska M, Podsiad M, Czeczot $H$. Expression and activity of superoxide dismutase isoenzymes in colorectal cancer. Acta Biochim Pol 2009;56:663-670.

47. Olson SH, Carlson MD, Ostrer H, Harlap S, Stone A, Winters $\mathrm{M}$, et al. Genetic variants in SOD2, MPO, and NQO1, and risk of ovarian cancer. Gynecol Oncol 2004;93:615-620.

48. Lorch JH, Thomas TO, Schmoll HJ. Bortezomib inhibits cell-cell adhesion and cell migration and enhances epidermal growth factor receptor inhibitor-induced cell death in squamous cell cancer. Cancer Res 2007;67:727-734.

49. Lorch JH, Klessner J, Park JK, Getsios S, Wu YL, Stack MS, et al. Epidermal growth factor receptor inhibition promotes desmosome assembly and strengthens intercellular adhesion in squamous cell carcinoma cells. J Biol Chem 2004;279:37191-37200.

50. Crighton D, Wilkinson S, Ryan KM. DRAM links autophagy to p53 and programmed cell death. Autophagy 2007;3:72-74.

51. Crighton D, Wilkinson S, O'Prey J, Syed N, Smith $P$, Harrison PR, et al. DRAM, a p53-induced modulator of autophagy, is critical for apoptosis. Cell 2006;126:121134.

52. Mackay A, Urruticoechea A, Dixon JM, Dexter T, Fenwick K, Ashworth A, et al. Molecular response to aromatase inhibitor treatment in primary breast cancer. Breast Cancer Res 2007;9:R37.
53. Turashvili G, Bouchal J, Baumforth K, Wei W, Dziechciarkova M, Ehrmann J, et al. Novel markers for differentiation of lobular and ductal invasive breast carcinomas by laser microdissection and microarray analysis. BMC Cancer 2007;7:55.

54. Fields AP, Justilien V. The guanine nucleotide exchange factor (GEF) Ect2 is an oncogene in human cancer. Adv Enzyme Regul 2010;50:190-200.

55. Boelens MC, Kok K, van der Vlies P, van der Vries G, Sietsma H, Timens $W$, et al. Genomic aberrations in squamous cell lung carcinoma related to lymph node or distant metastasis. Lung Cancer 2009;66:372-378.

56. Hirata D, Yamabuki T, Miki D, Ito T, Tsuchiya E, Fujita $\mathrm{M}$, et al. Involvement of epithelial cell transforming sequence-2 oncoantigen in lung and esophageal cancer progression. Clin Cancer Res 2009;15:256-266.

57. Ingenuity Systems. Accessed, 2011 Oct 3. Avaiable from: http://www injenuity.com.

58. Chen C, Méndez E, Houck J, Fan W, Lohavanichbutr $\mathrm{P}$, Doody $\mathrm{D}$, et al. Gene expression profiling identifies genes predictive of oral squamous cell carcinoma. Cancer Epidemiol Biomarkers Prev 2008;17:2152-2162.

59. Severino $P$, Alvares AM, Michaluart $P$ Jr, Okamoto OK, Nunes FD, Moreira-Filho CA, et al. Global gene expression profiling of oral cavity cancers suggests molecular heterogeneity within anatomic subsites. $B M C$ Res Notes 2008;1:113.

60. Gemenetzidis E, Bose A, Riaz AM, Chaplin T, Young $\mathrm{BD}$, Ali $\mathrm{M}$, et al. FOXM1 upregulation is an early event in human squamous cell carcinoma and it is enhanced by nicotine during malignant transformation. PLOS One 2009;4:e4849

61. Knight JA, Onay UV, Wells S, Li H, Shi EJ, Andrulis IL, et al. Genetic variants of GPX1 and SOD2 and breast cancer risk at the Ontario site of the Breast Cancer Family Registry. Cancer Epidemiol Biomarkers Prev 2004;13:146-149.

62. Liu K, Bellam N, Lin HY, Wang B, Stockard CR, Grizzle WE, et al. Regulation of p53 by TopBP1: a potential mechanism for p53 inactivation in cancer. Mol Cell Biol 2009;29:2673-2693.

63. Vecchione A, Ishii $H$, Shiao $Y H$, Trapasso F, Rugge $M$, Tamburrino JF, et al. Fez1/lzts1 alterations in gastric carcinoma. Clin Cancer Res 2001;7:1546-1552.

64. Serrano-Fernández $P$, Möller S, Goertsches R, Fiedler $H$, Koczan D, Thiesen HJ, et al. Time course transcriptomics of IFNB1b drug therapy in multiple sclerosis. Autoimmunity 2010;43:172-178. 